\title{
Assessing nutrient adequacy from the crop contents of free-ranging indigenous chickens in rural villages of the Venda region of South Africa
}

\author{
T. Raphulu ${ }^{1,2}$, C. Jansen van Rensburg ${ }^{1 \#} \&$ J.B.J. van Ryssen ${ }^{1}$ \\ ${ }^{1}$ Department of Animal and Wildlife Sciences, University of Pretoria, Pretoria 0002, South Africa \\ ${ }^{2}$ Department of Agriculture Limpopo, Mara Research Station, P/Bag X2467, Makhado 0920, South Africa
}

(Received 11 September 2014; Accepted 15 April 2015; First published online 21 May 2015)

\author{
Copyright resides with the authors in terms of the Creative Commons Attribution 2.5 South African Licence. \\ See: http://creativecommons.org/licenses/by/2.5/za \\ Condition of use: The user may copy, distribute, transmit and adapt the work, but must recognise the authors and the South African \\ Journal of Animal Science.
}

\begin{abstract}
The aim of the study was to evaluate the nutritional status of scavenging chickens by assessing the composition of their crop contents. The study was conducted on 288 free-ranging indigenous chickens from six adjacent rural villages in Venda region of South Africa over three seasons (autumn, winter and spring). The chickens consumed grains, kitchen waste, seeds from the environment, plant materials, worms and insects, and some undistinguishable materials. Household waste accounted for $78.6 \%, 91.1 \%$ and $75.8 \%$ and materials of animal origin, including insects and worms, accounted for $7.4 \%, 10.4 \%$ and $16 \%$ of the crop content in autumn, winter and spring, respectively. Grains and kitchen waste consumption and macro- and micro-nutrient concentrations varied with season. The crude protein (CP) level of the crop contents of adult chickens in all seasons and the calcium and phosphorus levels in winter corresponded with the requirements of poultry for maintenance and growth, but not egg production. Supplementation of CP to young birds in all seasons and calcium and phosphorus in autumn and spring might be necessary to improve their growth. Concentrations of copper, manganese, zinc and cobalt were above the requirements of poultry, but below their maximum tolerance levels (MTL). Iron concentrations ranged from $2907 \mathrm{mg} / \mathrm{kg} \mathrm{DM}$ to $6424 \mathrm{mg} / \mathrm{kg} \mathrm{DM}$, which are well above MTL, suggesting potential detrimental effects on the birds if the iron in the crop contents is bioavailable. Aluminium concentrations ranged from $2256 \mathrm{mg} / \mathrm{kg} \mathrm{DM}$ to $4192 \mathrm{mg} / \mathrm{kg} \mathrm{DM}$, though aluminium is considered non-toxic. It was concluded that the birds would not suffer from micro-mineral deficiencies, and that a risk of toxicity would depend on the bioavailability of the consumed element.
\end{abstract}

Keywords: Chemical composition, heavy metals, household waste, nutritional status

\# Corresponding author: christine.jansenvanrensburg@up.ac.za

\section{Introduction}

In rural communities of Vhembe district in Venda region of South Africa (hereafter Vhembe), poultry production is based on traditional scavenging systems at household level. A local eco-type, the Venda chicken, is the predominant type of chicken. It is adapted to the production system and is an efficient converter of scavengeable feed resources into eggs and meat (Fourie \& Grobbelaar, 2003). An improvement in indigenous chicken production in the region could increase the access of rural communities to quality protein in the form of meat and eggs. This should contribute to their health and socio-economic wellbeing. However, any advances in the productivity of free-ranging indigenous chickens would require close attention to nutritional, breeding and health aspects.

In recent studies, the growth potential of the Venda chicken (Norris et al., 2007), and its protein (Mbajiorgu et al., 2011) and metabolizable energy (Alabi et al., 2013) requirements have been investigated under confined optimal management conditions. However, traditional scavenging systems are low input methods in which the production of the animal is usually adjusted to feed availability, implying that the producer has to rely on what is locally and seasonally obtainable (Schiere \& De Wit, 1993). Rashid et al. (2004) pointed out that if the capacity of the scavenging feed resource base and seasonal variations are known, more efficient strategies for improved production of scavenging chickens could be developed, though it is impossible to formulate diets without reliable values for nutrient requirements, nutrient composition and daily intake of available feed (Roberts \& Gunarantne, 1992).

In many studies worldwide, the physical and nutrient compositions of crop contents have been investigated to obtain information about the feed ingredients that scavenging chickens take in and the 
nutrient composition of what they consume (Sonaiya, 2004; Goromela et al., 2008; Mekonnen et al., 2010). From this information, the nutritional status of the birds can be estimated, based on the assumption that if the concentration of a nutrient in crop contents indicates a deficiency, the chickens are likely to consume insufficient quantities of that nutrient. It would therefore be possible to obtain reliable information about possible nutrient deficiencies and excesses in the diets. Based on this, recommendations could be made for supplementing nutrients to overcome apparent nutritional problems, which could be implemented if this is feasible under that subsistence husbandry condition.

From investigations of the crop contents of chickens under free-ranging management conditions in rural villages, the general conclusion is that the nutrient composition of crop contents varies widely with season, climatic conditions and locality (Rashid et al., 2004; Sonaiya, 2004; Goromela et al., 2008; Mekonnen et al., 2010). Results from one study cannot be extrapolated to another situation.

Few, if any, studies have been conducted in terms of evaluating the composition of the nutrient intake of free-ranging Venda-type chickens in the rural communities of Vhembe. Such information would assist in identifying possible constraints that inhibit the productivity of the chickens, and could lead to the addition of dietary supplements to meet the nutritional requirements of these chickens and improve their output. The objective of the present study was to establish the nutrient composition of the feed consumed by free-ranging indigenous chickens in Vhembe in various seasons to assess the nutrient adequacy of their diets. Special attention was given to the concentration of mineral elements in their feed, an aspect that has not been covered by similar studies in which the assessment of nutrient adequacy was based on the composition of crop contents.

\section{Materials and Methods}

The study was approved by the Animal Use and Care Committee of the University of Pretoria (EC00808). Two hundred and eighty eight free-ranging indigenous chickens, predominantly of the Venda type (Grobbelaar et al. 2010), were randomly purchased from six adjacent rural villages, namely Tshifudi, Tshidzini, Tshamutshedzi, Tshivhilwi, Tshitereke and Makhuvha, which are situated at latitude S22 48 to $\mathrm{S} 22^{\circ} 53$ and longitude E30 28 to E30 42 in Thulamela Municipality, Vhembe, Limpopo, South Africa. Vhembe is regarded as a tropical (humid) region with an average annual rainfall of $820 \mathrm{~mm}$. The peak rainfall occurs in January - February (an average of more than $184 \mathrm{~mm}$ per month), while less than $20 \mathrm{~mm}$ occur monthly in the winter period (Mpandeli, 2014). The birds were collected over three seasons (autumn: April; winter: July; and spring: October), 96 chickens per season. Eight young chickens (four males and four females), 10 - 16 weeks old, four mature cockerels and four mature hens that have had at least one laying cycle were purchased from each of the six villages. Summer was not included in the study as birds are kept indoors during this period to prevent them from scavenging newly planted crops. The main crops in the area are maize, groundnuts and vegetables.

The birds were caught while scavenging between 14:00 and 17:00, weighed and immediately killed humanely by cervical dislocation. They were eviscerated and the crop contents were collected. The crop contents were categorised visually into eight main components, as presented in Table 1, weighed and ovendried for $48 \mathrm{~h}$ at $60{ }^{\circ} \mathrm{C}$. To measure the chemical composition, the dried crop contents were pooled according to class of bird (sex and age group) and season. Villages constituted the six replications. Dried crop contents were milled to pass through a $0.5 \mathrm{~mm}$ screen.

Dry matter (DM), ash, moisture and ether extract (EE) levels were obtained according to AOAC (2000) procedures. Crude protein (CP) was determined by the Dumas combustion procedure (Leco CNS 2000; Leco, St. Joseph, Mich, USA) and crude fibre (CF) with Fibre-Tech apparatus (Robertson \& Van Soest, 1981). Calcium (Ca), copper $(\mathrm{Cu})$, iron $(\mathrm{Fe})$, manganese $(\mathrm{Mn})$, zinc $(\mathrm{Zn})$, cobalt $(\mathrm{Co})$, vanadium $(\mathrm{V})$, cadmium (Cd), lead $(\mathrm{Pb})$, chromium $(\mathrm{Cr})$ and aluminium $(\mathrm{Al})$ analyses were done with a Perkin Elmer Atomic Spectrophotometer (Giron, 1973). Phosphorus (P) analysis was carried out with the Spekol 1300 apparatus using the spectrophotometric method (AOAC, 2000). Nitrogen-free extracts (NFE) was calculated by difference as: $1000-(C P+C F+A s h+E E+$ moisture $)$. An indirect method of Wiseman (1987) was used to calculate true metabolizable energy $(\mathrm{TME})$ as TME $(\mathrm{kcal} / \mathrm{kg} \mathrm{DM})=3951+54.4 \mathrm{EE} \%-88.7 \mathrm{CF} \%-40.8$ ash\%. Apparent metabolizable energy (AME) was calculated by assuming that TME is $8 \%$ (Wiseman, 1987) higher than AME. The conversion factor of 238.85 kilocalorie (kcal) equivalents to 1 megajoule (MJ) was used to convert kcal to MJ.

Statistical significance between carcass weight and physical and chemical composition of dry crop contents between treatments (bird age group, sex and season) was determined by an analysis of variance with the GLM model of SAS Institute (SAS, 2010). The following model:

$Y_{i j k l}=\mu+S_{i}+A_{j}+X_{k}+(S A)_{i j}+(S X)_{i k}+(A X)_{j k}+E_{i j k l}$ 
was employed and a 5\% significant level was used, where $Y_{\mathrm{ijkl}}$ is an observation for a given variable; $\mu$ is the general mean common to all observations; $S_{i}$ is the effect due to ith season; $A_{j}$ is the effect due to the jth age class of chicken; $X_{k}$ is the effect due to the kth effect of the sex group of chickens; $(S A)_{i j}$ is the interaction effects between the ith season and jth age; $(S X)_{i k}$ is the effects between the jth age and kth sex class; $(A X)_{j k}$ is the effects between the jth age and $k$ th sex group and $E_{i j k l}$ is the random error. Differences among means were determined by the least significant difference (LSD) procedure of SAS (2010).

\section{Results}

The physical components of the crop contents of the chickens are presented in Table 1.

Table 1 Description of physical components of crop contents of free-ranging indigenous chickens in the Vhembe district in Limpopo, South Africa

\begin{tabular}{|c|c|}
\hline Type of feed & Physical components \\
\hline Grains and seeds (cultivated) & Maize, baked maize, groundnuts, beans and sorghum \\
\hline Household $(\mathrm{HH})$ waste: plant origin & $\begin{array}{l}\text { Cooked cabbage, maize by-products, brewers' waste } \\
\text { residues, porridge, pieces of bread, tomatoes, cooked } \\
\text { rice, beetroot, vegetables and sweet potatoes }\end{array}$ \\
\hline Household $(\mathrm{HH})$ waste: animal origin & $\begin{array}{l}\text { Chicken feet bones and scales and intestines, } \\
\text { eggshells, meat and fish scraps, feathers }\end{array}$ \\
\hline Seeds from the environment & Grasses and fruits \\
\hline Other plant materials from the environment & Green leaves of vegetables and grasses \\
\hline Worms and insects & $\begin{array}{l}\text { Locusts, small ants and ant-like insects, termites, small } \\
\text { millipedes, centipedes, ticks, earthworms, small snails, } \\
\text { cockroaches, small crickets and flies }\end{array}$ \\
\hline Undistinguishable and miscellaneous materials & $\begin{array}{l}\text { Various feed particles, pieces of glass, plastic and } \\
\text { battery paper }\end{array}$ \\
\hline Grit & Small stones \\
\hline
\end{tabular}

The household $(\mathrm{HH})$ waste of plant origin could be attributed to kitchen leftovers (porridge and its waste products), maize by-products (bran and maize meal) and brewers' waste from local traditional beer. Dry maize grains are processed at the nearest mill (threshing) or manually to produce maize meal for human consumption, while winnowing and drying are done at the homesteads. The major part of kitchen waste of plant origin was porridge, which is the staple meal of the community.

Percentages of the components of dry crop contents for each season are indicated in Table 2. The main components of the crop contents varied $(P<0.05)$ with season, except for seeds from the environment, grit and undistinguishable materials $(P>0.05)$. There were good supplies of grains in autumn and $\mathrm{HH}$ waste of plant origin in spring and winter. The proportion of grains and $\mathrm{HH}$ waste of both animal and plant origin to total crop contents varied with season $(P<0.05)$. The presence of grains differed $(P<0.05)$ between seasons, constituting $54.5 \%, 22.5 \%$ and $10.7 \%$ of the total in autumn, winter and spring, respectively. The decrease in grains was accompanied by an increase in $\mathrm{HH}$ waste of plant origin. The $\mathrm{HH}$ waste of plant origin differed $(P<0.05)$ between seasons. Kitchen waste was highest in spring $(46.9 \% \mathrm{HH}$ waste of plant origin), while maize by-products and brewers' waste were highest in winter. The proportion of $\mathrm{HH}$ waste of animal origin was highest in winter. Season by age interaction influenced $\mathrm{HH}$ waste of animal origin $(P$ $<0.05)$. Some sunflower seeds were observed in the crop contents of birds in autumn when sunflowers were harvested. There was no effect of age, sex and age $x$ sex interaction $(P>0.05)$ on the proportion of the main components of the crop contents. Season $\mathrm{x}$ age interaction $(P<0.05)$ was observed for $\mathrm{HH}$ waste of animal origin. Adult chickens consumed more $\mathrm{HH}$ waste of animal origin (12.28\% dry crop content) in winter than growers in autumn (1.42\%) and spring (3.98\%). Adult chickens tended to consume more $\mathrm{HH}$ waste of plant and animal origin and less grains, plant materials, worms and insects than growers. However, in general, differences between age and sex groups were negligible for type of crop component.

Bodyweight of the chickens at slaughter varied with season, age and sex $(P<0.05)$. Adult males had a slaughter weight of $2067 \mathrm{~g}$ and adult females a slaughter weight of $1713 \mathrm{~g}$. The heaviest chickens were recorded in winter and the lightest in spring. Weight at slaughter and chemical composition of the crop contents are summarised in Tables 3 and 4. 
Table 2 Effect of season on physical composition of dry crop contents of free-ranging indigenous chickens

\begin{tabular}{|c|c|c|c|c|c|}
\hline \multirow{2}{*}{$\begin{array}{l}\text { Components } \\
\text { (\% dry crop content) }\end{array}$} & \multicolumn{3}{|c|}{ Season } & \multirow{2}{*}{ SEM } & \multirow{2}{*}{$P$ values } \\
\hline & Autumn & Winter & Spring & & \\
\hline Grains & $54.5^{\mathrm{a}}$ & $22.5^{\mathrm{b}}$ & $10.7^{c}$ & 3.09 & 0.0001 \\
\hline $\mathrm{HH}$ waste of plant origin & $22.8^{b}$ & $60.4^{\mathrm{a}}$ & $61.6^{\mathrm{a}}$ & 3.65 & 0.0001 \\
\hline Kitchen waste* & $19.1^{\mathrm{c}}$ & $31.2^{\mathrm{b}}$ & $46.9^{a}$ & 3.80 & 0.0001 \\
\hline Maize by-products* & $3.64^{b}$ & $27.0^{\mathrm{a}}$ & $12.9^{\mathrm{b}}$ & 3.41 & 0.0001 \\
\hline Brewers' waste* & $0.0^{\mathrm{b}}$ & $4.38^{\mathrm{a}}$ & $1.88^{\mathrm{ab}}$ & 1.30 & 0.0611 \\
\hline $\mathrm{HH}$ waste of animal origin & $1.34^{\mathrm{b}}$ & $8.29^{a}$ & $3.70^{\mathrm{b}}$ & 1.39 & 0.0016 \\
\hline Seeds & 0.43 & 1.27 & 0.31 & 0.44 & 0.0544 \\
\hline Other plant materials & $10.03^{a}$ & $4.17^{b}$ & $6.97^{\mathrm{ab}}$ & 1.50 & 0.0240 \\
\hline Worms and insects & $6.07^{\mathrm{b}}$ & $2.06^{b}$ & $12.0^{\mathrm{a}}$ & 1.84 & 0.0008 \\
\hline Grit & 0.91 & 0.15 & 1.80 & 0.78 & 0.2618 \\
\hline Indistinguishable materials & 3.98 & 1.20 & 3.01 & 1.40 & 0.7428 \\
\hline
\end{tabular}

Table 3 Slaughter weight of chickens, and dry matter (DM) and chemical composition of crop contents of free-ranging indigenous chickens, as influenced by season

\begin{tabular}{|c|c|c|c|c|c|}
\hline \multirow{2}{*}{ Parameter } & \multicolumn{3}{|c|}{ Season } & \multirow{2}{*}{ SEM } & \multirow{2}{*}{$P$ value } \\
\hline & Autumn & Winter & Spring & & \\
\hline Slaughter weight (g) & $1854^{a b}$ & $2033^{a}$ & $1783^{b}$ & 75.8 & 0.0544 \\
\hline DM in crop, \% body weight & 0.84 & 0.88 & 0.58 & 0.14 & 0.2225 \\
\hline Crude protein (g/kg DM) & 113 & 130 & 118 & 4.80 & 0.1283 \\
\hline Crude fibre (g/kg DM) & 36.9 & 34.2 & 32.9 & 1.82 & 0.4291 \\
\hline Ether extract (g/kg DM) & 40.2 & 50.9 & 40.2 & 6.7 & 0.3234 \\
\hline NFE (g/kg DM) & $649^{a}$ & $592^{b}$ & $590^{\mathrm{b}}$ & 17.9 & 0.0580 \\
\hline Ash (g/kg DM) & $84^{b}$ & $120^{\mathrm{ab}}$ & $139^{\mathrm{a}}$ & 7.7 & 0.0002 \\
\hline Calc. AME (MJ/kg DM) & $13.47^{\mathrm{a}}$ & $13.2^{\mathrm{a}}$ & $12.68^{\mathrm{b}}$ & 0.24 & 0.0549 \\
\hline
\end{tabular}

The NFE and ash levels of the crop contents varied with season $(P<0.05)$ (Table 3$)$. A CP level of 130 $\mathrm{g} / \mathrm{kg} \mathrm{DM}(P>0.05)$ of the crop contents was observed in winter, followed by $118 \mathrm{~g} \mathrm{CP} / \mathrm{kg} \mathrm{DM}$ and $113 \mathrm{~g}$ CP/kg DM in spring and autumn, respectively. Ash content differed with season $(P<0.05)$, with the lowest ash content being observed in autumn and the highest in spring. Season did not influence $(P>0.05)$ CF and EE levels, but differences $(P<0.05)$ between seasons were recorded for AME and NDF. No significant differences were observed on the effect of age and sex on the chemical composition of the crop contents, except that age (Table 4) had a significant effect on AME content $(P<0.05)$. There was a tendency for the growing chickens to consume feed with a higher CP content and lower CF content than adults. Crop contents from adult birds had a higher $(P<0.05)$ ash content than growers. 
Table 4 Slaughter weight of chickens, dry matter (DM) and chemical composition of crop contents of freeranging indigenous chickens, as influenced by age

\begin{tabular}{lllll}
\hline Parameter & Adult & Grower & SEM & P values \\
\hline Slaughter weight (g) & $2788^{\mathrm{a}}$ & $992^{\mathrm{b}}$ & 62.0 & 0.0001 \\
DM in crop, \% body weight & $0.59^{\mathrm{a}}$ & $0.94^{\mathrm{b}}$ & 1.09 & 0.0240 \\
Crude protein (g/kg DM) & 118 & 123 & 5.4 & 0.4940 \\
Crude fibre (g/kg DM) & 36.5 & 33.0 & 1.85 & 0.186 \\
Ether extract (g/kg DM & 41.4 & 46.1 & 5.47 & 0.5401 \\
NFE (g/kg DM & 608 & 614 & 14.8 & 0.5172 \\
Ash (g/kg DM) & 123 & 105 & 7.86 & 0.1186 \\
Calc. AME (MJ/kg DM & $12.81^{\mathrm{b}}$ & $13.46^{\mathrm{a}}$ & 0.19 & 0.0181 \\
abc Means with different superscripts within a row differed significantly at $P<0.05$. & \\
NFE: nitrogen-free extract; Calc. AME: calculate apparent metabolizable energy.
\end{tabular}

The $\mathrm{Ca}$ and $\mathrm{P}$ levels of the crop contents varied with season. In winter the $\mathrm{Ca}$ and $\mathrm{P}$ levels were higher $(P<0.05)$ than in the other seasons (Table 5). Age by sex interaction had an effect on Ca in the crop contents $(P<0.05)$. The crop contents of adult females, grower males, adult males and grower females had a Ca content of $11.7 \mathrm{~g} / \mathrm{kg} \mathrm{DM}, 7.47 \mathrm{~g} / \mathrm{kg}$ DM, $6.52 \mathrm{~g} / \mathrm{kg}$ DM and $3.90 \mathrm{~g} / \mathrm{kg} \mathrm{DM}$, respectively.

Table 5 Mineral element composition of crop contents of free-ranging indigenous chickens as influenced by season

\begin{tabular}{lccccc}
\hline \multirow{2}{*}{ Elements } & \multicolumn{3}{c}{ Season } & SEM & P value \\
\cline { 2 - 4 } & Autumn & Winter & Spring & & \\
\hline Calcium (g/kg DM) & $5.35^{\mathrm{b}}$ & $10.87^{\mathrm{a}}$ & $5.58^{\mathrm{b}}$ & 1.66 & 0.0336 \\
Phosphorus (g/kg DM) & $3.11^{\mathrm{b}}$ & $4.82^{\mathrm{a}}$ & $3.06^{\mathrm{b}}$ & 0.53 & 0.0327 \\
Aluminium (mg/kg DM) & $2256^{\mathrm{b}}$ & $3901^{\mathrm{a}}$ & $4192^{\mathrm{a}}$ & 3.12 & 0.0001 \\
Cadmium (mg/kg DM) & $0.22^{\mathrm{b}}$ & $0.35^{\mathrm{a}}$ & $0.30^{\mathrm{ab}}$ & 0.02 & 0.0019 \\
Chromium (mg/kg DM) & $18.8^{\mathrm{b}}$ & $25.4^{\mathrm{b}}$ & $47.5^{\mathrm{a}}$ & 4.48 & 0.0065 \\
Cobalt (mg/kg DM) & $8.11^{\mathrm{b}}$ & $9.35^{\mathrm{ab}}$ & $9.53^{\mathrm{a}}$ & 0.42 & 0.0951 \\
Copper (mg/kg DM) & 11.04 & 12.61 & 12.75 & 0.99 & 0.4469 \\
Iron (mg/kg DM) & $2907^{\mathrm{b}}$ & $4624^{\mathrm{a}}$ & $4617^{\mathrm{a}}$ & 495 & 0.0697 \\
Lead (mg/kg DM) & $7.06^{\mathrm{a}}$ & $6.54^{\mathrm{a}}$ & $2.67^{\mathrm{b}}$ & 1.09 & 0.0141 \\
Manganese (mg/kg DM) & $64.0^{\mathrm{b}}$ & $93.9^{\mathrm{ab}}$ & $99.0^{\mathrm{a}}$ & 9.69 & 0.0763 \\
Vanadium (mg/kg DM) & $8.36^{\mathrm{b}}$ & $15.52^{\mathrm{a}}$ & $18.37^{\mathrm{a}}$ & 1.45 & 0.001 \\
Zinc (mg/kg DM) & 55.2 & 60.0 & 67.1 & 5.38 & 0.3459 \\
\hline abc Means with different superscripts within a row differed significantly at $P<0.05$. & & \\
SEM: standard error of mean. & & & &
\end{tabular}

The trace element concentrations of the crop content of the chickens as influenced by season are summarized in Table 5. Aluminium, $\mathrm{Pb}, \mathrm{Cd}, \mathrm{V}$ and $\mathrm{Cr}$ concentrations varied with season $(P<0.05)$. The crop contents of $\mathrm{Al}$ and $\mathrm{V}$ in spring and winter were significantly $(P<0.01)$ higher than those in autumn. Season did not influence $\mathrm{Cu}, \mathrm{Zn}$ and $\mathrm{Co}$ concentrations, but between seasons $\mathrm{Fe}$ and $\mathrm{Mn}$ concentrations were different $(P<0.05)$. Mean concentrations of the elements over all seasons were $(\mathrm{mg} / \mathrm{kg} \mathrm{DM})$ : $\mathrm{Al}, 3491 ; \mathrm{Cd}$, 0.29; $\mathrm{Cr}, 30.5$; $\mathrm{Co}, 9.0 ; \mathrm{Cu}, 12.1 ; \mathrm{Fe}, 4049 ; \mathrm{Pb}, 5.4 ; \mathrm{Mn}, 85.6 ; \mathrm{V}, 14.3$ and $\mathrm{Zn} 60.8$. Season $\mathrm{x}$ age and season $\mathrm{x}$ sex interactions on $\mathrm{Pb}$ were observed $(P<0.05)$. In autumn, crop contents of growers contained 
more $\mathrm{Pb}(10.47 \mathrm{mg} / \mathrm{kg} \mathrm{DM})$ than adults $(3.65 \mathrm{mg} / \mathrm{kg} \mathrm{DM})$, while those obtained from females contained more $\mathrm{Pb}(10.46 \mathrm{mg} / \mathrm{kg} \mathrm{DM})$ than from males $(3.65 \mathrm{mg} / \mathrm{kg} \mathrm{DM})$.

\section{Discussion}

The bodyweight of the adult birds of $2788 \mathrm{~g} \pm 61.4 \mathrm{~g}$ compares well with the mature weight of $2819 \mathrm{~g}$ for male Venda chickens reported by Norris et al. (2007) in a growth study in which they were fed optimally to measure their growth curves. The birds in the present study might not all have been pure Venda chickens, but the comparison between adult weights suggests that they received sufficient nutrients to ensure that, at least, they did not suffer permanent stunting during the growth phase. In winter the birds were heavier than in the other seasons (Table 3). This could simply be because of variations in sampling, considering the limited numbers of birds per sex and age groups in each season.

Since the feed components in the crop at a specific time of day represent only a fraction of total DM intake per day, the concentrations of nutrients in the crop content can be used only as an indication of diet composition. In general, differences in chemical composition of crop contents between localities are the result of differences in climate, which are determined by type of vegetation and availability of feed in the environment (Ologbobo, 1990). However, in a review of studies in which the composition of crop contents was evaluated, Goromela et al. (2006) concluded that, on average, diets consumed by scavenging chickens were deficient in energy, protein, $\mathrm{Ca}$ and $\mathrm{P}$. In the present study the amount of $\mathrm{HH}$ waste accounted for the major proportion of the total crop contents, with $78.6 \%, 91.1 \%$ and $75.8 \%$ in autumn, winter and spring, respectively. These results are in agreement with the findings of Goromela et al. (2008) and Rashid et al. (2005). An advantage of this high proportion of household waste is that the birds' owners can add supplements through this portion of the diet if deficiencies are identified.

Alabi et al. (2013) reported that diets containing $12.34 \mathrm{MJ} \mathrm{ME} / \mathrm{kg} \mathrm{DM}$ to $12.91 \mathrm{MJ} \mathrm{ME} / \mathrm{kg} \mathrm{DM}$ supported optimal feed intake, growth rate and feed conversion ratios during the starter and grower phase of Venda chicks under well-controlled management conditions. In the present study the high AME of 12.7 $\mathrm{MJ} / \mathrm{kg} \mathrm{DM}$ to $13.5 \mathrm{MJ} / \mathrm{kg} \mathrm{DM}$ of crop contents suggests that the fowls had access to diets that were high in energy. These high energy levels are supported by the relatively low CF levels of $<40 \mathrm{~g} \mathrm{CF} / \mathrm{kg} \mathrm{DM}$ in the crop contents compared with $54 \mathrm{~g}$ CF $/ \mathrm{kg}$ recommended by Gunaratne et al. (1993) for commercial hens. High NFE levels (590 to $649 \mathrm{~g} / \mathrm{kg}$ ), indicating soluble carbohydrates, were recorded (Table 3) and support the high ME levels in the crop content. However, since these high ME levels reflect the quality of the diet and not how much energy the birds consumed per day, it is not possible to conclude that these free-ranging chickens consumed sufficient energy to meet their requirements, especially since a large "activity increment" would probably have to be added to their energy requirements.

According to NRC (1994), the recommended levels of CP in diets for growing chickens (not broilers) range from $150 \mathrm{~g} / \mathrm{kg} \mathrm{DM}$ to $200 \mathrm{~g} / \mathrm{kg} \mathrm{DM}$ and for mature chickens from $100 \mathrm{~g} / \mathrm{kg}$ DM to $160 \mathrm{~g} / \mathrm{kg} \mathrm{DM}$. Mbajiorgu et al. (2011) raised Venda chickens in closed confinement from day old to 13 weeks old on diets containing 12.2 MJ ME/kg DM and varying levels of $\mathrm{CP}$. The authors concluded that an energy : protein ratio of between $60 \mathrm{MJ} \mathrm{ME} / \mathrm{kg}$ and $63 \mathrm{MJ} \mathrm{ME} / \mathrm{kg}$ protein optimized feed intake, growth rate and feed conversion ratio for this type of chicken. In the present study, the CP levels of the crop contents ranged between 113 $\mathrm{g} / \mathrm{kg} \mathrm{DM}$ and $130 \mathrm{~g} / \mathrm{kg} \mathrm{DM}$, and did not differ significantly between age groups, while the energy : protein ratio for both adults and growers was $109 \mathrm{MJ} \mathrm{ME} / \mathrm{kg}$ DM crop contents. It appears therefore as if the birds did not receive adequate levels of dietary protein to support efficient production.

Although amino acid composition is a determining factor in assessing protein sufficiency of birds (Boisen et al., 2000), 7.4\%, 10.4\% and 16\% of the $\mathrm{HH}$ waste were from animal origin, plus insects and worms (Table 2), assumedly with a well-balanced amino acid content (Mlcek et al., 2014). This could indicate that the mature birds received sufficient protein. Mwalusanya et al. (2002) recorded that the crop content of chickens in Tanzania contained $104 \mathrm{~g} \mathrm{CP} / \mathrm{kg}$ DM, and Mekonnen et al. (2010) reported a level of 129 - $150 \mathrm{~g}$ $\mathrm{CP} / \mathrm{kg}$ in chickens in Ethiopia. In the present study the highest CP level was observed in winter, the driest season, when there is no abundance of insects and worms. This trend could be because of a higher consumption of household materials of animal origin in winter.

A problem with interpreting nutrient concentrations in crop contents is that the quantity of feed consumed is unknown. Total intake of a nutrient may be insufficient to meet the requirements of the birds, even if the concentration in the crop contents indicates adequacy. In addition, if insufficient quantities are ingested of a nutrient with the highest priority in the body, such as energy and protein, responses to the supplementation of other nutrients might be ineffective, except for those with antioxidant properties (Cronje et al., 2006).

The ash content of the crop contents of 84,120 and 139 for autumn, winter and spring, respectively, is well above recommended concentrations given in the NRC (1994). Since the percentage of grit in the crop 
contents was low, ranging from $0.15 \%$ to $1.8 \%$, it is likely that dust and soil that could not be detected in the crop contents, contributed to this high ash content.

The crop contents of adult females, grower males, adult males and grower females had Ca levels of $11.7 \mathrm{~g} / \mathrm{kg} \mathrm{DM}, 7.57 \mathrm{~g} / \mathrm{kg} \mathrm{DM}, 6.5 \mathrm{~g} / \mathrm{kg}$ DM and $3.9 \mathrm{~g} / \mathrm{kg} \mathrm{DM}$, respectively. Total P levels of the crop contents were more constant $(3.1-4.8 \mathrm{~g} / \mathrm{kg}$ ) and not affected by age, sex or season. Both $\mathrm{Ca}$ and total $\mathrm{P}$ contents in the crop were relatively low compared with NRC (1994) recommendations for layer- and meat-type poultry. A Ca concentration of approximately $8.8 \mathrm{~g} / \mathrm{kg}$ DM for broilers and $35 \mathrm{~g} / \mathrm{kg}$ DM for leghorn layers was recommended by Rama Rao et al. (2003) at low dietary phosphorus levels ( $3.5 \mathrm{~g}$ and $2.8 \mathrm{~g}$ of non-phytin $\mathrm{P} / \mathrm{kg}$ feed, respectively). It is well documented that adult laying hens tend to select feedstuffs with higher levels of $\mathrm{Ca}$ than other chicken classes because of their higher $\mathrm{Ca}$ requirements to synthesize the eggshell (Payne, 1990; Mwalusanya et al., 2002). Since about $0.50-0.80$ total $P$ in plant feedstuffs is bound as phytate $\mathrm{P}$ (Steiner et al., 2007), which is poorly available to monogastric animals (Pointillart et al., 1984) it can be concluded that the chickens in this study had a low intake of P. Supplementation of $\mathrm{Ca}$ and $\mathrm{P}$ seems to be necessary to improve the nutritional status of the local chickens, which in turn should improve their productivity.

Identifying deficiencies in the diets of free-ranging chickens in rural communities is valuable in planning a strategy to overcome nutritional problems. However, in most cases the owners of these birds do not have the financial means to purchase supplements for them. Van Ryssen et al. (2014) demonstrated that wood ash is a good source of $\mathrm{Ca}$, and can replace feed lime in the diets of broilers. Calcium supplementation is therefore a possibility in Vhembe, because wood ash is available from homestead fires. However, it is unlikely that pure ash would be consumed by the chickens, and would have to be mixed with other $\mathrm{HH}$ waste. In addition, caution when feeding homestead ash was expressed by Van Ryssen \& Ndlovu (2003) because of impurities in it. A further problem is that the ideal $\mathrm{Ca}$ to non-phytin $\mathrm{P}$ ratio in the diet could be disrupted with wood ash supplementation.

The concentration of the transition elements $\mathrm{Cu}, \mathrm{Fe}, \mathrm{Mn}, \mathrm{Zn}$ and $\mathrm{Co}$ did not vary significantly between seasons. The concentrations of these elements were well above the requirements of meat and leghorn chickens as reported by NRC (1994), and, except for Fe, were within the maximum tolerance level (MTL) as suggested by NRC (2005). The only concern is that high concentrations of $\mathrm{Cu}, \mathrm{Mn}, \mathrm{Zn}$ or Co might be antagonistic to elements that are low in the crop content. It is well documented that soil ingestion by animals can have a significant effect on trace mineral ingestion, implying that the elements in soil are bioavailable. Judson \& McFarlane (1998) pointed out that in ruminants under normal grazing conditions ingested soil can be a source of mineral elements such as Fe, iodine (I) and Mn. Neser et al. (1997) found that young calves with a pre-ruminant, that is, a monogastric, digestive system consuming soil high in $\mathrm{Mn}$, developed $\mathrm{Mn}$ toxicity owing to the accumulation of $\mathrm{Mn}$ in their livers. Suttle et al. (1984) demonstrated that when sheep consumed soils that are high in $\mathrm{Fe}, \mathrm{Cu}$ absorption was suppressed. It can be assumed that these elements in soil were available to the birds to a certain extent, supplying their requirements.

Iron concentration varied from $2907 \mathrm{mg} / \mathrm{kg}$ DM to $6424 \mathrm{mg} / \mathrm{kg}$ DM in the crop contents. Suttle (2010) pointed out that all species have high tolerance towards dietary Fe. However, high dietary levels of Fe are antagonistic to the absorption of Cu (Suttle et al., 1984) and Mn (Suttle, 2010). The NRC (2005) concluded that Fe toxicity ranges from $500 \mathrm{mg} / \mathrm{kg}$ to $4500 \mathrm{mg} / \mathrm{kg}$, depending on the bioavailability of the Fe source. According to Suttle (2010), tolerable Fe concentrations have been set for poultry at $1000 \mathrm{mg} / \mathrm{kg}$. However, the author indicated that these levels depend on total available Fe intake. Where exogenous Fe sources have low relative biological values, such as in soil, tolerable levels would be much higher. Van Ryssen et al. (1993) recorded excessively high concentrations of Fe (16762 mg/kg DM) in the pure excreta of "backyard" chickens. These samples were collected in the Pietermaritzburg area of South Africa, but not from rural households. They concluded that the Fe must have originated mainly through the consumption of soil.

Prinsen Geerlings et al. (2003) suggested that food prepared in iron cooking pots could be used to overcome Fe deficiency in developing countries. However, in southern Africa there tends to be Fe overload in human beings in rural communities (Walker \& Segal, 1999). In Vhembe three-legged cast iron pots are used extensively for cooking. Residues from food prepared in these pots could well be a major source of the high Fe concentration in the crop contents in the present study.

Aluminium concentrations in the crop contents varied from $2256 \mathrm{mg} / \mathrm{kg}$ DM to $4192 \mathrm{mg} / \mathrm{kg}$ DM. Aluminium is classified as non-toxic (Reilly, 1991), though in the summary of mineral tolerances in animals (NRC, 2005) studies are quoted in which the consumption of certain Al salts elicited toxic symptoms in chickens. A cautious maximum tolerance level of $1000 \mathrm{mg} / \mathrm{kg} \mathrm{DM}$ was suggested by the NRC (2005). Van Ryssen et al. (1993) recorded a concentration of $9885 \mathrm{mg} \mathrm{Al} / \mathrm{kg}$ in pure backyard excreta, and concluded that the Al originated from geophagia. Rao \& Rao (1995) pointed out that Al contaminates food prepared in aluminium cooking pots, though in Vhembe the use of Al cooking pots is rare. The most likely source of $\mathrm{Al}$ in 
the crop contents is ingested soil, and it is probably not a health concern in free-ranging chickens because of an assumed low Al bioavailability.

The highest concentration of $\mathrm{Pb}(7.06 \mathrm{mg} / \mathrm{kg})$ was obtained in autumn, but it was lower than the MTL of $10 \mathrm{mg} / \mathrm{kg}$ DM suggested by the NRC (2005). Vanadium concentration ranged between $8.36 \mathrm{mg} / \mathrm{kg} \mathrm{DM}$. and $18.37 \mathrm{mg} / \mathrm{kg}$ DM. Vanadium concentrations in winter and spring were higher than the MTL of $10 \mathrm{mg} / \mathrm{kg}$ $\mathrm{DM}$ in diets for poultry (NRC, 2005), which might affect egg quality. However, bioavailability of the $\mathrm{V}$ source often determines whether the $\mathrm{V}$ in the crop contents in winter and spring poses a risk to or a negative effect on the chickens. The mean concentration of $\mathrm{Cd}$ ranged between $0.22 \mathrm{mg} / \mathrm{kg} \mathrm{DM}$ and $0.35 \mathrm{mg} / \mathrm{kg} \mathrm{DM}$, and the highest concentration was obtained in winter. Cadmium levels were found to be less than the permissible limit of $0.5 \mathrm{mg} / \mathrm{kg} \mathrm{DM}(\mathrm{NRC}, 2005)$, which indicates that Cd toxicity is not a risk to chickens in Vhembe.

\section{Conclusions}

Crop contents of chickens reflect not only the availability of nutrients in the environment, but also the selective feeding habits of birds, which are related to their nutritional requirements. However, crop nutrient contents at any time do not indicate total daily feed intake or utilization of nutrients. Therefore, any recommendation based on crop content of nutrients should take into consideration that crop content is only a guideline, because there are many other important factors such as scavenging area, foraging habit and density of the chickens.

From the concentration of nutrients in the crop contents of free-ranging chickens in Vhembe it could be concluded that the birds probably consume insufficient quantities of protein, $\mathrm{Ca}$ and $\mathrm{P}$. It seems feasible to supplement $\mathrm{Ca}$ through adding wood ash to their diets, though caution should be taken not to upset the dietary $\mathrm{Ca}$ : available $\mathrm{P}$ ratio within a class of birds. Although the results suggest that supplementation of high-quality protein and available $\mathrm{P}$ would be beneficial to the birds, for practical and economic reasons it might be more difficult to achieve under these subsistence husbandry conditions.

The concentration of $\mathrm{Al}, \mathrm{Cu}, \mathrm{Fe}, \mathrm{Mn}, \mathrm{Zn}$ and $\mathrm{Co}$ in the crop contents were above the requirements of poultry, though below the MTL of the element, except for very high Fe and Al concentrations. It is suggested that most of these elements were obtained through ingesting soil and dust, and consequently would probably have a relatively low bioavailability in the bird, including $\mathrm{Al}$, which is considered non-toxic. However, the high Fe concentrations might have also originated from cast iron pots used for cooking food in the region, and Fe from these pots could have accumulated in the feed consumed by the birds. There seems to be no need for the supplementation of trace minerals in the diets of the birds in the region, though further studies might be necessary to establish the bioavailability of the elements in the feed consumed by the birds.

\section{Acknowledgments}

The authors wish to acknowledge the support of National Research Foundation (NRF) for funding the research work. We are grateful to chicken farmers and Limpopo Department of Agriculture for their support.

\section{References}

Alabi, O.J., Ng'ambi, J.W. \& Norris, D., 2013. Dietary energy level for optimal productivity and carcass characteristics of indigenous Venda chickens raised in closed confinement. S. Afr. J. Anim. Sci. 43 (Suppl. 1), S75-S80.

AOAC, 2000. Official Methods of Analysis. 17th ed. The Association of Official Analytical Chemists. Alington, V.A., USA.

Boisen, S., Hvelplund, T. \& Weisbjerg, M.R., 2000. Ideal amino acid profiles as a basis for feed protein evaluation. Livest. Prod. Sci. 64, 239-251.

Cronjé, M.C., Van Ryssen, J.B.J. \& Coertze, R.J., 2006. Potential benefit of trace element supplementation of sheep on a low level of nutrition. S. Afr. J. Anim. Sci. 36, 20-27.

Fourie, C. \& Grobbelaar, J.A.N., 2003. Indigenous Poultry Breeds. Wingnut Publications, Krugersdorp, South Africa.

Giron, H.C., 1973. Perkin Elmer Atomic Spectrophotometer. Atomic Absorption Newsletter 12, 28.

Goromela, E.H., Kwakkel, R.P., Verstegen, M.W.A. \& Katule, A.M., 2006. Strategies to optimize the use of scavengeable feed resource base by smallholders in traditional poultry production systems in Africa: A review. Afr. J. Agric. Res. 1, 91-100.

Goromela, E.H., Kwakkel, R.P., Verstegen, M.W.A. \& Katule, A.M., 2008. Effect of season and farming system on the quantity and nutritional quality of scavengeable feed resources and performance of village poultry in central Tanzania. J. Cell Anim. 2, 063-071.

Grobbelaar, J.A.N., Sutherland, B. \& Molalakgotla, N.M., 2010. Egg production potentials of certain indigenous chicken breeds from South Africa. Anim. Genet. Resour. 46, 25-32. 
Gunaratne, S.P., Chandrasiri, D.N., Mangalika Hemalatha, W.A.P. \& Roberts, J.A., 1993. Feed resource base for scavenging chickens in Sri Lanka. Trop. Anim. Health Prod. 25, 249-257.

Judson, G.J. \& McFarlane, J.D., 1998. Mineral disorders in grazing livestock and the usefulness of soil and plant analysis in the assessment of these disorders. Aust. J. Exp. Agr. 38, 707-723.

Mbajiorgu, C.A., Ng'ambi, J.W. \& Norris, D., 2011. Effect of varying dietary energy to protein ratio level on growth and productivity of indigenous Venda chickens. Asian J. Anim. Vet. Adv. 6, 344-352

Mekonnen, H., Kelay, B. \& Berhan, T., 2010. Assessment of the nutritional status of indigenous scavenging chickens in Ada'a district, Ethiopia. Trop. Anim. Health Prod. 42, 123-130.

Mlcek, J., Rop, O., Borkovcova, M. \& Bednarova, M., 2014. A comprehensive look at the possibilities of edible insects as food in Europe - a review. Pol. J. Food Nutr. Sci. 64, 147-157.

Mpandeli, S., 2014. Managing climate risks using seasonal climate forecast information in Vhembe District in Limpopo Province, South Africa. J. Sustain. Develop. 7, 68-81.

Mwalusanya, N.A., Katule, A.M., Mutayoba, S.K., Minga, U.M., Mtambo, M.M.A. \& Olsen, J.E., 2002. Nutrient status of crop contents of rural scavenging local chickens in Tanzania. Br. J. Poult. Sci. 43, 64-69.

Neser, J.A., De Vries, M.A., De Vries, M., Van der Merwe, A.J., Loock, A.H., Smith, H.J.C., Van der Vyver, F.H., Elsenbroek, J.H. \& Delport, R., 1997. The possible role of manganese poisoning in enzootic geophagia and hepatitis of calves and lambs. J. S. Afr. Vet. Assoc. 68, 2-7.

Norris, D., Ng'ambi, J.W., Benyi, K., Makgahlela, M.L., Shimelis, H.A. \& Nesamvuni, E.A., 2007. Analysis of growth curves of indigenous male Venda and Naked Neck chickens. S. Afr. J. Anim. Sci. 37, 21-26.

NRC, 1994. Nutrient Requirements of Poultry. Ninth revised ed. National Academies of Science, Washington D.C., USA.

NRC, 2005. Mineral Tolerance of Animals. Second revised ed. National Research Council, The National Academies of Science, Washington D.C., USA.

Ologhobo, A.D., 1990. Feed and feeding in extensive poultry production systems. Entwicklung LandicherRaum 24, 15-17.

Payne, W.J.A., 1990. An Introduction to Animal Husbandry in the Tropics. 4th ed. Longman Scientific and Technical, Essex and New York. pp. 684-744.

Pointillart, A., Fontaine, N. \& Thomasset, M., 1984. Phytate phosphorus utilization and intestinal phosphatases in pigs fed low phosphorus: wheat or corn diets. Nutr. Rep. Int. 29, 473-483.

Prinsen Geerlings, P.D., Brabin, B.J. \& Omari, A.A.A., 2003. Food prepared in iron cooking pots as an intervention for reducing iron deficiency anaemia in developing countries: a systematic review. J. Human Nutr. Diet. 16, 275-281.

Rama Rao, S.V., Panda, A.K., Raju, M.V.L.N., Shyam Sunder, G. \& Praharaj, N.K., 2003. Requirement of calcium for commercial broilers and white leghorn layers at low dietary phosphorus levels. Anim. Feed Sci. Technol. 106, 199-208.

Rao, K.S.J. \& Rao, G.V., 1995. Aluminium leaching from utensils - a kinetic study. Int. J. Food Sci. Nutr. 46, 31-38.

Rashid, M., Chandra, B. \& Asaduzzaman, V., 2004. Chemical composition of crop contents of local scavenging chickens. Pakistan J. Nutr. 3, 26-28.

Rashid, M.M., Islam, M.N., Roy, B.C., Jakobsen, K. \& Lauridsen, C., 2005. Nutrient concentrations of crop and gizzard contents of indigenous scavenging chickens under rural conditions of Bangladesh. Livestock Research for Rural Development 17, http://www.cipav.org.co/lrrd//rrd17/2/rash17016.htm (Retrieved June 18, 2009).

Reilly, C., 1991. Metal Contamination of Food. Second edition, Elsevier Scientific Publishers, LTD, New York, USA.

Roberts, J.A. \& Gunarantne, S.P., 1992. The scavenging feed resource base for village chickens in a developing country. In: Proceedings of the 19th World Poultry Congress, Amsterdam; The Netherlands. 1, 822-825.

Robertson, J.B. \& Van Soest, P.J., 1981. In: The Analysis of Dietary Fiber in Food. Eds: James, W.P.T. \& Theander, O., Dekker, New York, USA.

SAS, 2010. Statistical Analysis Systems, Users' Guide. (5th ed.) (Version 9.2). SAS Institute Inc., Cary, N.C., USA.

Schiere, J.B. \& De Wit, J., 1993. Feeding standards and feeding systems. Anim. Feed Sci. Technol. 43, 121-134.

Sonaiya, E.B., 2004. Direct assessment of nutrient resources in free range and scavenging systems. Regional report. Wrld Poult. Sci. J. 60, 523-535. 
Steiner, T., Mosenthin, R., Zimmermann, B., Greiner, R. \& Roth, S., 2007. Distribution of phytase activity, total phosphorus and phytate phosphorus in legume seeds, cereals and cereal by-products as influenced by harvest year and cultivar. Anim. Feed Sci. Technol. 133, 320-334.

Suttle, N.F., 2010. Mineral Nutrition of Livestock. 4th Edition, CABI, Cambridge, UK.

Suttle, N.F., Abrahams, P. \& Thornton, I., 1984. The role of a soil $x$ dietary sulphur interaction in the impairment of copper absorption by ingested soil in sheep. J. Agric. Sci. 103, 81-86.

Van Ryssen, J.B.J. \& Ndlovu, H., 2003. Wood and homestead ash as potential source of minerals to livestock. In: Proc. $8^{\text {th }}$ Wrld Congr. Anim. Prod., Porto Allegro, Brazil. 2003, ID 9713.

Van Ryssen, J.B.J., Van Malsen, S. \& Verbeek, A.A., 1993. Mineral composition of poultry manure in South Africa with reference to the Farm Feed Act. S. Afr. J. Anim. Sci. 23, 54-57.

Van Ryssen, J.B.J., Phosa, M.A. \& Jansen van Rensburg, C., 2014. Different levels of macadamia oil cake meal, and wood ash vs. feed lime as dietary sources of calcium on bone characteristics of slowgrowing chickens. S. Afr. J. Anim. Sci. 44, 71-79.

Walker, A.R.P. \& Segal, I., 1999. Iron overload in Sub-Saharan Africa: to what extent is it a public health problem? Br. J. Nutr. 81, 427-434.

Wiseman, J., 1987. Feeding of Non-ruminant Livestock. Butterworth, London, UK. pp. 9-13. 